\title{
Are Brazilian dentists and dental students using the ICCC recommendations for caries management?. Braz Oral Res. 2020;34:e062. https://doi.org/10.1590/1807-3107bor-2020. vol34.0062
}

Table 3

Where is read:

Table 3. ICCC sentences and level of agreement ( 1 - totally disagree, 2 - partially disagree, 3 - do not know, 4 - partially agree, 5 - totally agree).

\begin{tabular}{lcc}
\hline ICCC sentences & $\begin{array}{c}\text { Level of } \\
\text { agreement }\end{array}$ & $\mathrm{n}(\%)$ \\
\hline $\begin{array}{l}\text { "Currently, carious tissue management of permanent } \\
\text { teeth is based on selective removal to avoid pulpal } \\
\text { exposure, and the parameters for removal are the clinical } \\
\text { criteria of hardness and depth. Residual contamination }\end{array}$ & 1 & $84(34.9)$ \\
below the restoration does not compromise the & 3 & $86(35.7)$ \\
restorative treatment." & 4 & $7(2.8)$ \\
\hline & 5 & $27(11.2)$ \\
\hline $\begin{array}{l}\text { "In deep lesions of vital pulp teeth, preservation of } \\
\text { pulp health should be prioritized, thereby allowing soft/ }\end{array}$ & 3 & $104(43.3)$ \\
leathery dentin to be maintained over the pulp." & 2 & $60(25)$ \\
& 4 & $4(1.7)$ \\
\hline $\begin{array}{l}\text { "Selective removal up to firm dentin is the treatment of } \\
\text { choice for both shallow and medium cavitated carious }\end{array}$ & 3 & $21(8.7)$ \\
\hline $\begin{array}{l}\text { lesions." } \\
\text { as complete excavation or complete removal of carious } \\
\text { tissue, is no longer recommended as an approach for }\end{array}$ & 3 & $101(21.3)$ \\
\hline
\end{tabular}




\section{It should read:}

Table 3. ICCC sentences and level of agreement ( 1 - totally disagree, 2 - partially disagree, 3 - do not know, 4 - partially agree, 5 - totally agree).

\begin{tabular}{|c|c|c|}
\hline ICCC sentences & Level of agreement & n (\%) \\
\hline \multirow{5}{*}{$\begin{array}{l}\text { "Currently, carious tissue management of permanent teeth is based on selective removal } \\
\text { to avoid pulpal exposure, and the parameters for removal are the clinical criteria of } \\
\text { hardness and depth. Residual contamination below the restoration does not compromise } \\
\text { the restorative treatment." }\end{array}$} & 5 & $84(34.9)$ \\
\hline & 4 & $86(35.7)$ \\
\hline & 3 & $7(2.8)$ \\
\hline & 2 & $37(15.4)$ \\
\hline & 1 & $27(11.2)$ \\
\hline \multirow{5}{*}{$\begin{array}{l}\text { "In deep lesions of vital pulp teeth, preservation of pulp health should be prioritized, } \\
\text { thereby allowing soft/leathery dentin to be maintained over the pulp." }\end{array}$} & 5 & $104(43.3)$ \\
\hline & 4 & $60(25)$ \\
\hline & 3 & $4(1.7)$ \\
\hline & 2 & $21(8.7)$ \\
\hline & 1 & $51(21.3)$ \\
\hline \multirow{5}{*}{$\begin{array}{l}\text { "Selective removal up to firm dentin is the treatment of choice for both shallow and } \\
\text { medium cavitated carious lesions." }\end{array}$} & 5 & $101(41.9)$ \\
\hline & 4 & $55(22.8)$ \\
\hline & 3 & $6(2.5)$ \\
\hline & 2 & $34(14.1)$ \\
\hline & 1 & $45(18.7)$ \\
\hline \multirow{5}{*}{$\begin{array}{l}\text { "Nonselective removal to hard dentin, formerly known as complete excavation or } \\
\text { complete removal of carious tissue, is no longer recommended as an approach for } \\
\text { carious lesion management." }\end{array}$} & 5 & $137(56.8)$ \\
\hline & 4 & $62(25.7)$ \\
\hline & 3 & $14(5.9)$ \\
\hline & 2 & $16(6.6)$ \\
\hline & 1 & $12(5)$ \\
\hline
\end{tabular}

